\title{
COVID-19 as a Scam Challenge
}

\author{
MILICA D. ĐEKIĆ, Cyber Defense Magazine, New York City, USA \\ GYULA MESTER, Óbuda University, Budapest, Hungary
}

Review paper

UDC: $343.721:: 004$

DOI: 10.5937/tehnika2101115D

\begin{abstract}
Any nature-related occurrence can be seen as a security threat as it puts under the risk the human lives, their well-being as well as the entire infrastructure. The natural disasters and pandemic events are by many classified as the threats and they can seriously make harm to the majority of people and their assets. In the practice, the recent pandemic occurrence such as the Ebola is recognized by the Interpol as a bio-terrorism. That illness has taken the lives to so many people in Africa and wider, but with the discovery of the vaccine the pandemic has been put under the control. Even now the similar situation is with the COVID-19 pandemic as such a biological threat is not fully manageable due to the lack of the immunization. However, there are some empirical indications suggesting that with the appearance of the critical situation so many people will show the solidarity and willingness to support those being in the need. On the other hand, not any appeal for a help will be honest and so many fraudsters can try to take advantage over the people's weaknesses. Those persons deal with the entire psychology of the victim and they can accurately choose the moment to attack and which strategy to use. Basically, what we talk about is the criminological challenge and it does not appear in the physical environment only but also in the cyberspace as the skillfully planned hacking operation. The reason why so many people get hooked with such a criminality is that the donations are symbolic, so the number of victims can increase as the majority will be willing to give the money away. In other words, so many victims will be in deception and the criminals will take only several dollars from each of them, so if the minority of the victims even report about such an event they will signalize that someone took the very small amount of the money from them and in such a case the punishment is so weak or even does not exist. The different schemes are present regarding the cybercrime as those criminal groups could try to avoid the severe punishment doing the camouflage in the virtual domain. Finally, the role of this effort is to provide a comprehensive insight into the challenges of such scams as well as analyze their impacts to communities.
\end{abstract}

Key words: fraud, cyber defense, pandemic, intelligence, case

\section{INTRODUCTION}

The COVID-19 pandemic is a situation that made many aspects of our lives to struggle. As it is known, any emergency occurrence seeks from the people to change or at least re-organize some of their daily activities. The impacts of this event are obvious nearly anywhere and it seems that such a situation has turned the entire world upside down. In other words, there are a lot of details that should be fixed or consequently put into order. This sort of the effort is not the medical one by its content and summary, so right here we will mostly deal with the security aspects of the pandemic.

Author's address: Milica Đekić, Vase Pelagića 39, Subotica

e-mail: milicadjekic82@gmail.com

Paper received: 08.01.2021.

Paper accepted: 28.01.2021.
As we said, the security connotation will suggest us it's all about the threat and even if it is the naturerelated happening we can classify so as the risk to the people and their assets. On the other hand, in the industry and commerce the workforce is from the critical significance to the production cycle and the losses to the entire economy could be huge if the employees do not operate due to the health concerns. The similar situation is literally in any sector of the society as those sorts of events are highly capable to paralyze our everyday life and functioning. Basically, it will appear that such a small and meaningless virus can sabotage the entire nations and their countries. If it is about the bio-weapon we can notice its impacts are so far reaching. In this case, we cannot talk with the confidence if it is about the bio-terrorism, but it's quite obvious that such a microbe can stop us in our attempt to defeat all the values of the modern and healthy life we have the right to lead in our communities. 
Apparently, the immunization can seem as the counterresponse to such an event, but the way of creating and approving the medication can take time and finances, as well. Also, we will recognize the entire pandemic as the event being threatening to many and it's logical those events can occur from time to time. Maybe in some future times we could think on some kind of the event-based security as the human and non-human threats can appear occasionally.

In addition, the pandemic conditions have developed the need for a better risk management as the threat for the quality of life increases. This pandemic has caused the serious number of the dead cases and in such a fashion it's clear why finding the response to so must be from the vital importance. The majority of the countries across the world have recommended the preventive measures and that sort of strategy has given some positive results. On the other hand, the common people will mainly see so as restrictions and they can even choose to protest against such imposed measures from their governments. Either the corona virus has been created in the nature or some lab it's obvious it will make a lot of damage as its impacts to the people's well-being are so catastrophic. In other words, it seems such a microbe will literally terrorize the nations and give so non-peaceful nap to their state agencies. Also, the immunization could be the good response to such a situation, but our environment can come with its new creation being much more dangerous and with the higher percentage of mortality amongst the wide population. The point is to cope with the scientific research methodologies that can recognize the tendencies in the epidemiology, molecular biology and genetics in order to do some sort of the predictive analytics in those branches of the medicine. Indeed, those kinds of researches have given us the chance to relatively quickly develop the first vaccines as the first-hand response to that situation. Further, the new challenge is to make any heavy disease being curable, so that means anyone with the diagnosis can recover fully and deeply.

The people living in the time of the pandemic have developed the solidarity about each other and that sort of care is something that makes us humans. Nowadays so many media will overwhelm us with the stories on some conspiracy theories claiming that corona virus does not exist and all so is the matter of propaganda. The good question to these sorts of speculations could be who is beneficial from those sorts of media campaigns. On the other hand, if modified in the lab this virus is the great human-made threat; oppositely - if the nature gave us such a powerful bio-weapon the good remark can be how we can take control over such weaponry. In other words, there are a plenty of things that we do not know at this stage, but what we know for certain is so many community members deal with the empathy about one another and no one would want to be the potential victim of that illness. It seems we have gotten the new, bad guy in our neighborhood that can terrorize even if it is so small and invisible its impacts are so unpleasant to the entire communities. Next, the time of crisis will make the people feel the solidarity and closeness about everyone and they will be willing to share what they have with anyone being in the need for such a support. Apparently, we have said the virus is that little bad guy, but it is nothing in comparation with the criminal underworld. Therefore, if anyone is in the need for a help the people will do their best to support. There could be the entire humanitarian actions that will seek from the members of the public to donate the symbolic money in order to assist to someone. Those sorts of activities can be with the bad intent and the real bad guys can take advantage over someone's humanity and caring manners. In other words, in the state of emergency many of us can become the victims of the scam as our willingness to give can be arising. In this effort, we will discuss that sort of the crime and try to analyze some of those perspectives.

\section{COMMON FRAUD CHALLENGES}

The common fraud is a criminality that can put some individuals into delusion and those persons are the victims of the crime in order to assure some sort of financial advantage or the other interests to the person or the group of persons committing that offense. The fraudsters will mainly choose the overcrowded places to commit the scam as at those spot they can be less obvious. On the other hand, there is the wide spectrum of methodologies in criminology and policing best practice that can offer the clues to the investigators, so apparently they can prove that sort of occurrence. In the practice, the punishments to the frauds are quite weak and from that perspective there is the strong need to define much heavier punishment policies. The mass scams are possible if they are organized on the busy places or include more criminal actors that can obtain the extremely busy schedule. By the frequent schedule we mean sending the bad guys to many different places in, say, some urban or rural areas to collect the donations for something being in the focus of the public at that period of time. The majority of criminalities can happen if the criminals find the vulnerabilities with their victims and further continue to exploit their weaknesses to their own advantage. Many people are sensitive to the needs of the other people being under the threat and no matter if it's about the natural disaster or the refugee crisis they will be open to support. Also, there could be a plenty of so stressful stories about some personal tragedies and in the developed world no one will feel sorry to donate $\$ 100$ 
or \$200 in order to contribute. Those people will mostly think it's not a big deal giving that help and if anyone is that greedy to trick the people looking for that donation that's the shame, but not the real reason to believe anyone is disadvantaged.

In other words, no one will have a heart to say no to such touchy narratives. Especially if the donation collectors' message is that such a gesture will save someone's life - that cannot be the better reason to feel as someone's hero and indeed, many people will appreciate to think like so about themselves. Moreover, that's the strategy the majority of scammers will use in order to play with the psychology of the victim and make him willingly give that donation.

Being in position to do some sharing is a beautiful emotion and many of us will enjoy being from the help to the people being in the need. Apparently, some of those appeals are true, but from time to time there are the seasons when the scammers are the most active. Giving some symbolic money to some humanitarian purposes is right, but if the collectors cannot convince anyone they are sent by some creditable organization it's better to avoid such a support and report the situation to the authorities.

In the practice, there are so many situation when it's necessary to hesitate if it's really needed to be supportive or just the entire case should be forwarded to the Police. For instance, someone can send the sick children to collect the money for their purposes and such a scene can be so heartbreaking, but the fact is that poor thing can be the victim of much serious crime such as the human trafficking - so any information of that sense can be contributive to the authorities.

In addition, there are a lot of online scams that can make the people donate some money using the credit cards. Maybe they will donate several dollars, but if we assume that the millions of the people can be tricked it's clear that the income for a fraudster is so significant. Next, we will talk a bit about the challenges of the COVID-19 scams as that situation has called so many people to show the solidarity and deal in the mature and responsible manner.

\section{VULNERABILITIES TO HEALTH NEEDS}

The COVID-19 is a health challenge that can put the human life under the risk. It's hard thinking how some persons are unwell and how they suffer. In other words, we all are vulnerable to the health needs of others as we can easily imagine ourselves into such a position.

So, if someone is unhealthy today, we could be like so even tomorrow. Especially, in the case of the transferrable infection everyone can catch that microbe and smoothly get into so dangerous and even life threatening condition. So, from that perspective it can appear that it's a rational decision giving a donation for the COVID-19 needs. It's only the symbolic sum and no one will feel unpleasant to share that money with anyone kindly asking for so. Basically, we all can identify with such a case and if we are generous about the other people, they will probably revenge to us in the same manner. That's how nearly everyone thinks if the donation's collector comes on his doors and asks for some support. Also, so many of us will get that appeal online and we all will be willing to do an epayment in order to support someone being in the need wishing we will never need that sort of the help.

The experienced fraudsters will know the psychology of the ordinary people and they will so ruthlessly play on that card. In other words, anyone of us can be in the need for something and that's why so many people will show the solidarity and even care about the poor ones.

The majority of scammers are well-familiar with those people's weaknesses and they usually choose the strategies to touch our hearts. Anyone with the good heart cannot say no to such a request and that's the reason why the most of the people will donate that money literally feeding the parasites of our communities. Only in the cases when the authorities issue the warnings about the seasonal scams so many of us can become open to freely talk about the experiences they had in their community or on the web - otherwise they can remain so blind in front of the suspicious situations.

\section{FAKE HUMANITARIAN CAMPAIGNS}

It's well-known that the reputable and creditable organizations can arrange some sorts of the humanitarian activities. In such a case the public will be informed through the media and the internet suggesting to everyone to take part in such an action. So suddenly, our e-mail inbox and social media accounts can be overwhelmed with the appeals for some donations that should support someone being in the need. Those messages could be fully convincible and many of us can make a decision to donate some money. The common people can give, say, $\$ 100$ per person, while the businesses can share much more as they are in position to do so. This can sound as so attractive to the entire fraudsters' underworld as they can make the fake online campaigns or even choose to collect the money in person. Apparently, the operation can use so diverse channels to trick the community members and take advantage over their willingness to give. Further, we will illustrate how it works doing the scam in some environment. 


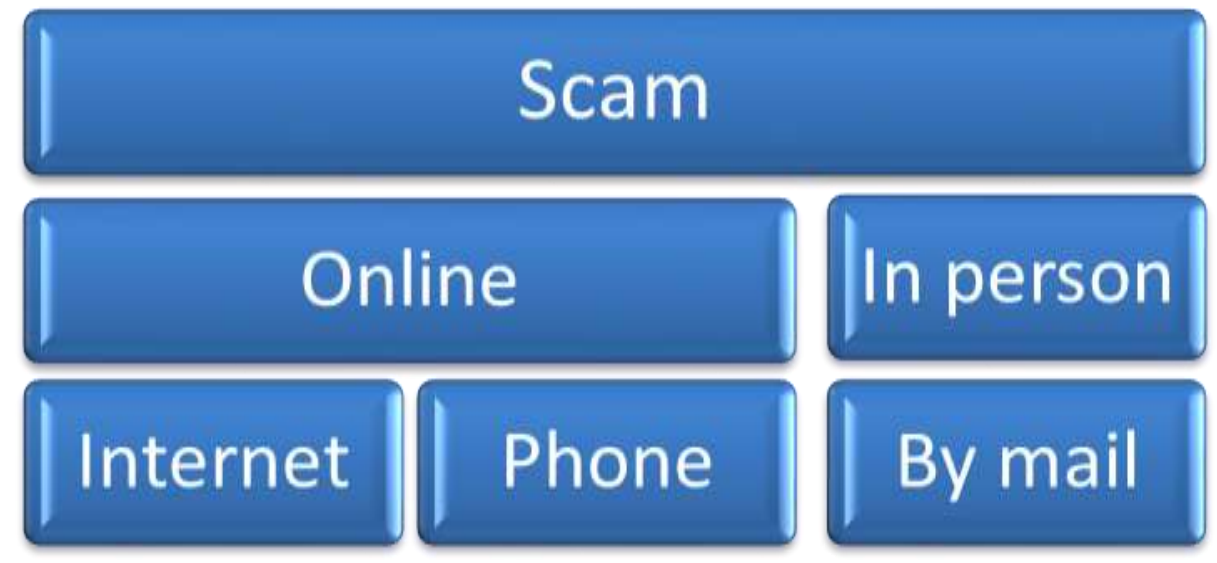

Figure 1 - Typical frauds in the practice

As it is given in the Figure 1 the common scams can appear in person or online. The online frauds can go through the phone or via the internet. On the other hand, the frauds happening in person can go so directly and in some cases they can occur through the post service. In this effort, we will talk about the COVID19 scam challenges, but through this study it's obvious the reason to commit the scam can vary and the motive is always the same - the money. The fraudsters will select to do what they do if they estimate the risk is minimal and the profit could be good enough. In other words, those guys are the professional criminals ready to do anything to obtain the huge income. Next, in this article we will discuss how it works when the fraudsters' and cybercrime underworld are united to conduct so serious joint actions and leave the majority of us without money as well as make the severe headache to the law enforcement officers, so far.

\section{RISK TO PHISHING ATTACKS}

In the practice, there are so many findings about the COVID-19 pandemic being available to the public. In other words, either we can read the different opensource intelligence being accessible on the web or watch the TV program about so the effects are mostly the same - the situation is so engaging and many people will develop the interest to know a lot about such a case. On the other hand, if we surf on the internet trying to figure out what is happening and how so promptly everything became correlated with everything we will leave the footage about our IP address and it's well-known that if anyone deals with anyone's IP address that person or the group can attack such an asset. One of the most critical challenges to the ongoing cyber defense is the phishing attack. Mainly it's about the phishing links that can give us the malware or simply receive our device details. It's quite trickery if the cyber criminals and fraudsters find the same language and make a decision to conduct some kind of the joint operations in order to take advantage over the people's and machine's weaknesses. The modern findings will suggest that in this time of crisis the percentage of cyber attacks have increased so significantly. Either being the COVID-19 or anything else it's clear that the events being in the focus of the public can be the good trigger to far more serious illegal activities. Above all, either being the scammers or the hackers the bad guys can make the difficult situation being much harder and put already exhausted people and the entire system into so critical condition.

\section{IMPACTS TO COMMUNITIES}

Any critical situation can make so deep injuries to the entire community as those conditions will weaken everyone and they can also be time consuming and it's clear if something takes time it takes our finances as well. So, the health's crisis can run the economic instability and that's seriously hard to experience. If we add that under those circumstances the crime booms it's obvious why it's so challenging to manage the both - health and security risk.

At the beginning of this effort, we have mentioned that any nature-related occurrence can be the security threat, so it's clear why it's so heavy to handle such many threats. Moreover, we will lose the money for the crisis and also there will be some scammers taking from us the rest. Such a situation can appear as so frustrating and seriously it's the security challenge that must be tackled - otherwise we all can collapse, so far. There is some remark that we can handle the problem only if we admit it exists, so once we get aware of such a concern we will be capable to involve the entire community to actively participate into its resolution.

\section{DISCUSSION}

The COVID-19 is a medical condition that has shaken the entire world so dramatically. Practically, it has risen into the entire global crisis as it is the case with the other pandemic events. In other words, we all 
are exhausted with that situation and probably the immunization can be the right answer to that concern. Throughout history there have been so many pandemics and in those cases the human kind lost so many lives, but at the end there will come the cure.

No matter how pessimistic our perspectives are today we must stay positive for a reason no time was easy and we should realize this will also pass. Apparently, at any end there will remain the hope.

\section{CONCLUSION}

Finally, the fraud challenges being correlated with the pandemic situation are only so small pieces in the mosaic that can illustrate how hard it is combating the crime in the time of crisis. Under such a condition it's necessary to seek the better organization of the both human and non-human resources as it can be the relief to such a challenging event.

In conclusion, the response to such a challenge should be strong and impactful as it is possible under this state, so far.

\section{REFERENCES}

[1] Mester G. Cloud Robotics Model, Interdisciplinary Description of Complex Systems, Vol. 13, No. 1, ISSN 1334-4684, DOI:10.7906/indecs.13.1.1. pp. 18, 2015.

[2] Mester G, Rodic A, Simulation of Quad-rotor Flight Dynamics for the Analysis of Control, Spatial Navigation and Obstacle Avoidance, In Proc. 3rd International Workshop on Advanced Computational Intelligence and Intelligent Informatics (IWACIII 2013), Shanghai, China, ISSN: 2185-758X, pp. 1-4, October 18 to 21 in 2013.

[3] Mester G. Massive Open Online Courses in Education of Robotics, Interdisciplinary Description of Complex Systems, Croatien Interdisciplinary Society, Vol. 14, No. 2, ISSN 1334-4684, DOI: 10.7906 /indecs. 14.2.7, pp. 182-187, 2016.

[4] Mester G. Merenje rezultata naučnog rada, TEHNIKA, Belgrade, Serbia, Vol. 64, No. 3, ISSN 00402176, pp. 445-454, 2015.

[5] Mester G. Academic Ranking of World Universities 2009/2010, Ipsi Journal, Transactions on Internet Research, TIR, Belgrade, ISSN 1820 - 4503, Vol. 7, No. 1, pp. 44-47, 2011.

[6] Mester G. Novi trendovi naučne metrike, In Proc. XXI Skup Trendovi Razvoja: "Univerzitet u Promenama...", TREND 2015, Zlatibor, Serbia, ISBN 978-86-7892-680-8, DOI: 10.13140/RG.2.1.1754.2486, paper No. UP 1-3, pp. 23-30, 23 - 26. 02. 2015.
[7] Rodic A, Mester G. Control of a Quadrotor Flight, In Proc. ICIST Conference, Kopaonik, Serbia, ISBN: 978-86-85525-12-4, pp. 61-66, 03-06.03.2013.

[8] Mester G. Modeling of Autonomous Hexa-Rotor Microcopter, In Proc. IIIrd International Conference and Workshop Mechatronics in Practice and Education, MechEdu 2015, Subotica, Serbia, ISBN 97886-918815-0-4, pp. 88-91, May 14-16, 2015.

[9] Mester G, Rodic R, Navigation of an Autonomous Outdoor Quadrotor Helicopter, In Proc. 2nd International Conference on Internet Society Technologie and Management ICIST, Kopaonik, Serbia, ISBN: 978-86-85525-10-0, pp. 259-262, 01-03.03.2012.

[10]Mester G. Obstacle - Slope Avoidance and Velocity Control of Wheeled Mobile Robots Using Fuzzy Reasoning, In Proc. IEEE 13th International Conference on Intelligent Engineering Systems, INES 2009, Barbados, ISBN: 978-1-4244-4113-6, DOI: 10.1109/INES.2009.4924770, pp. 245-249, April 16$18,2009$.

[11]Mester G. Backstepping Control for Hexa-Rotor Microcopter, Acta Technica Corviniensis - Bulletin of Engineering, Tome VIII, Fascicule 3, ISSN 20673809, pp. 121-125, July - September, 2015.

[12]Mester G. New Trends in Scientometrics, In Proc. of the SIP 2015, 33nd International Conference Science in Practice, Schweinfurt, Germany, pp. 22-27, 0708.05.2015.

[13]Kasac J, Milic V, Stepanic J, Mester G. Computational Approach to Parameter Identification of Spatially Distributed Nonlinear Systems with Unknown Initial Conditions, In Proc. IEEE Symposium on Robotic Intelligence in Informationally Structured Space RiiSS (2014), Orlando, Florida, USA. DOI: 10.1109/ IISS.2014.7009170, ISBN: 9781479944637, p. 154, Vol. 1, pp. 55-61, 9-12 December 2014.

[14]Mester G. Metode naučne metrike i rangiranja naučnih rezultata, In Proc. 57th ETRAN Conference, Zlatibor, Serbia, pp. RO3.5.1-3, 3-6. June 2013.

[15]Rodic A, Mester G. Ambientally Aware Bi-Functional Ground-Aerial Robot-Sensor Networked System for Remote Environmental Surveillance and Monitoring Tasks, In Proc. 55th ETRAN Conference, Section Robotics, Society for Electronics, Telecommunications, Computers, Automatic Control and Nuclear Engineering, Banja Vrućica, Bosnia and Herzegovina, Vol. RO2.5, ISBN 978-86-80509-66-2, pp. 1-4, June 6-9, 2011.

[16]Đekić M. D, Kako sačuvati kontinuitet u poslovanju uprkos cyber incidentima, TEHNIKA, Vol. 70, No. 2, pp. 346-349, 2015. 
[17]Đekić M.D, Cyber procedure za poslovno okruženje u Srbiji, TEHNIKA, Vol. 71, pp. 471-474, 2016.

[18]Đekić M. D, The Cloud's Computing Security, TEHNIKA, Vol. 73, No. 2, pp. 300-304, 2018.

[19]Đekić M. D, The Internet of Things Security, TEHNIKA, Vol. 72, No. 2, pp. 309-312, 2017.

[20]Đekić M. D, The Commerce Crime and Ways of Conducting a Financial Security, TEHNIKA, Vol. 71, No. 5, pp. 782-786, 2016.

[21]Đekić M. D, Cyber Procedures for a Business Environment in Serbia. Tehnika, Vol. 71, No. 3, pp. 471 474, 2016.

[22]Đekić M. D, The Internet of Things Cybersecurity Standardization, TEHNIKA, Vol. 74, No. 4, pp. 603 607, 2019.

[23]Đekić M. D, The Application of Marketing for Small and Medium-sized Enterprises Competiveness Rise in the Republic of Serbia, TEHNIKA, Vol. 72, No. 4, pp. 587-590, 2017.

[24]Đekić M. D, A Smart Configuration of Computer as a Prevention from Hacking and Cyber Espionage, TEHNIKA, Vol. 71, No. 5, pp. 761-764, 2016

[25]Đekić M. D, How to Create Training for the IT Industry's Staffs? TEHNIKA, Vol. 71, No. 4, pp. 644$647,2016$.

[26]Đekić M. D, How to Maintain a Business Continuity Despite Cyber Incidents? TEHNIKA, Vol. 70, No. 2, pp. 346-349, 2015.

[27]Đekić M. D, The Use of Video Detection as a Function of Traffic Safety, TEHNIKA, Vol. 66, No. 3, pp.471-475, 2011.

[28]Đekić M. D, How a modern business could respond to the Phishing Attack Challenges, TEHNIKA, Vol. 72, No.3, pp. 455-459, 2017.

\section{REZIME}

\section{COVID-19 KAO IZAZOV ZA PREVARE}

Svako dešavanje u prirodi može da se uoči kao bezbedonosna pretnja koja stavlja pod rizik ljudske živote, kvalitet življenja, kao i čitavu infrastrukturu. Elementarne nepogode i pandemisjki događaji su od strane mnogih klasifikovani kao pretnje, koje mogu da nanesu ozbiljnu štetu većini ljudi i njihovim objektima. U praksi, skorija pandemijska dešavanja poput Ebole su od strane Interpola prepoznata kao bio-terorizam. Ta bolest je uzela mnogo života u Africi $i$ šire, ali je pronalaženje vakcine sve to stavilo pod kontrolu. Slična situacija je i sa COVID-19 pandemijom kako ta biološka pretnja nije u potpunosti sanirana iz razloga nedostatka imunizacije. Međutim, postoje određene indikacije da takva situacija može kod ljudi da izazove potrebu za solidarnošću $i$ voljnost da pomognu svima kojima je pomoć neophodna. S druge strane, nije svaki poziv za pomoć pošten i jako mnogo prevaranata može da zloupotrebi te ljudske slabosti. Te osobe poznaju čitavu psihologiju žrtve i tačno znaju kada da napadnu $i$ koju strategiju da koriste. U osnovi, ono o čemu pričamo je kriminološki izazov i podjednako je zastupljen kako u fizičkom, tako $i$ u virtuelnom okruženju. Razlog zašto se ljudi upecaju na ovaj vid kriminaliteta je taj što su donacije simbolične, tako da je većina voljna da udeli svoj novac. Drugim rečima, mnoge žrtve su obmanute i kako kriminalci uzimaju svega nekoliko dolara, većina žrtava to ne prijavljuje i čak da policija sazna za to kazne su male ili ih uopšte nema. U visokotehnološkom prostoru se takođe dešavaju takve šeme, ali tada kriminalci koriste kamuflaže kako bi izbegli da budu kažnjeni. Konačno, uloga ovog rada je da pruži sveobuhvatni uvid u izazove takvih prevera, kao i da analizira njihove uticaje na zajednicu.

Ključne reči: prevara, visokotehnološka bezbednost, pandemija, saznanja, slučaj 